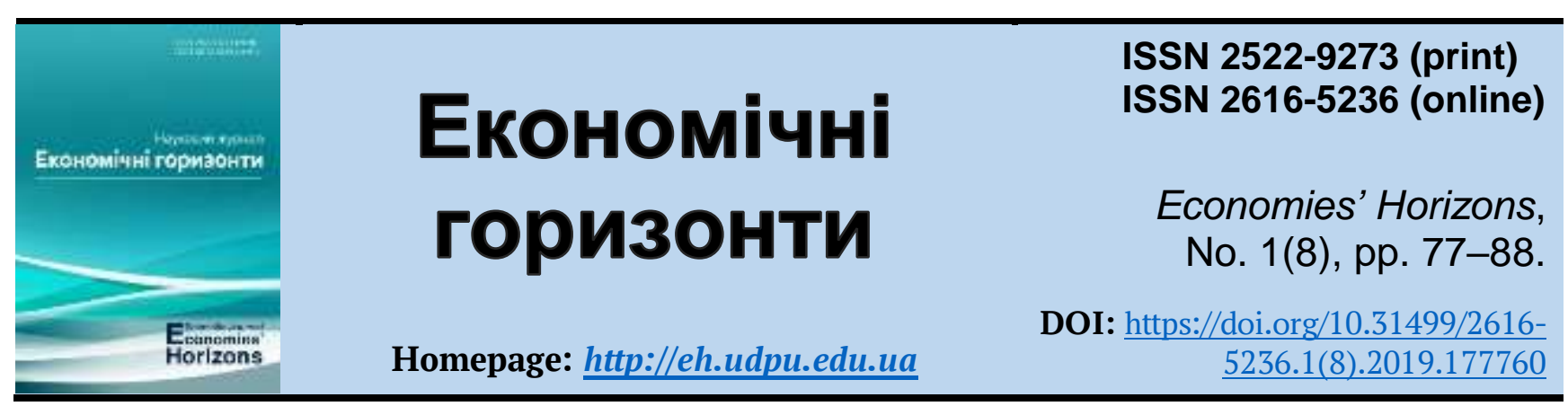

UDC 330.131.7:330.322

\title{
Influence of risks and state economic security treatments on foreign direct investments
}

\author{
Taisiya H. Bondaruk ${ }^{1}$, Doc. Ec. Sc., Professor \\ Oleh S. Bondaruk ${ }^{2}$, Cand. Ec. Sc. \\ Anna P. Kulish ${ }^{3}$, Cand. Ec. Sc., Associate Professor
}

Received: 15 March 2019

Accepted: 17 April 2019

\begin{abstract}
Bondaruk, T. H., Bondaruk, O. S. and Kulish, A. P. (2019), "Influence of risks and state economic security treatments on foreign direct investments", Economies' Horizons, no. 1(8), pp. 77-88, doi: https://doi.org/10.31499/2616-5236.1(8).2019.177760.
\end{abstract}

Abstract. The purpose of the research is to study risks and potential sources of economic security threats, as well as available and necessary resources to neutralize them. Methods. It was used the following methods: comparative economic analysis, induction and deduction, summarizing, logical generalization, grouping, graphic expression of statistical data. Results. The quantity and dynamics of entered foreign investments in Ukraine were analyzed during the last several years, investment attractiveness was evaluated based on international ratings. Assess of crisis situations is related to the identification and analysis of real and potential threats to economic security in its various segments and their impact attraction of direct foreign investments to the Ukrainian economy. The real fall of Ukraine's GDP and, as a consequence, the lowered asset values significantly limits the provision due to the economies of other components of national security as well as investment attractiveness of the country. Classification of threats to budget security based not only on their distribution in groups depending on various characteristics, but also the gradation of these groups according to their importance for economic development (this approach allows to identify and neutralize threats that pose the greatest danger to the economy). Practical meaning. It was justified, that for further improvement of the investment attractiveness of Ukraine, it is necessary to ameliorate legal and organizational base to guarantee the State economic security to provide favorable investment climate and develop competiveness of the national economy. Prospects for further research can be in the development conceptual basis of investment security of Ukraine taking into account the challenges and threats of globalization.

Keywords: foreign investment, economic security, threats to economic security, risks and threat sources, financial security, classification of threats.

\footnotetext{
${ }^{1}$ National Academy of Statistics, Accounting and Audit; Head of the Department of Finances, Banking and Insurance; ORCID ID: https://orcid.org/0000-0001-9410-6428; e-mail: bondaruk23@ukr.net.

${ }^{2}$ National Academy of Statistics, Accounting and Audit; Lecturer at the Department of Finances, Banking and Insurance; ORCID ID: https://orcid.org/0000-0002-3472-9516; e-mail: bondaruk001@ukr.net.

${ }^{3}$ Kyiv National Economic University named after Vadym Hetman; Professor at the Department of Corporate Finance and Controlling; ORCID ID: https://orcid.org/0000-0001-6189-9927; e-mail: kulish.anna@ukr.net.
} 
JEL Classification: E 20, F 21, H 10, J 28, Z 18.

Number of references: 18; number of tables: $\mathbf{0}$; number of figures: $\mathbf{6}$; number of formulas: $\mathbf{0}$.

\title{
Вплив ризиків та економічної безпеки держави на пряме іноземне інвестування
}

\author{
Т. Г. Бондарук ${ }^{1}$, д. е. н., професор \\ О. С. Бондарук ${ }^{2}$, к. е. н. \\ Г. П. Куліш ${ }^{3}$, к. е. н., доцент
}

Стаття надійшла: 15.03 .2019

Стаття прийнята: 17.04.2019

Bondaruk T. H., Bondaruk O. S., Kulish A. P. Influence of risks and state economic security treatments on foreign direct investments. Економічні горизонти. 2019. № 1(8). C. 77-88. DOI: 10.31499/2616-5236.1(8).2019.177760.

Анотація. Метою статті є дослідження ризиків та прямих джерел загроз економічній безпеці держави, а також у виявленні можливих та необхідних джерел їх нейтралізації. Методи. У статті використано наступні методи дослідження: порівняльний економічний аналіз, системний аналіз, індукція та дедукція, узагальнення, логічне узагальнення, групування, графічного вираження статистичних даних. Результати. У статті проаналізовано кількість та динаміку іноземних інвестицій в Україні за останні декілька років, здійснено оцінку якості інвестицій на основі міжнародних даних. Оцінка кризових ситуацій можлива відповідно до виявлення та аналізу реальних і можливих загроз економічній безпеці у їі різноманітних секторах та їхній привабливості для прямого іноземного інвестування в економіку України. Зниження ВВП України і, як наслідок, зменшена вартість активів суттєво обмежує забезпечення відповідно до заощаджень інших компонентів національної безпеки, а також привабливості країни для інвестицій. Класифікація загроз бюджетній безпеці грунтується не лише на їхньому розподілі в групах, які залежать від різних характеристик, а також на градації цих груп відповідно до їхньої важливості для економічного розвитку (такий підхід допомагає визначити та нейтралізувати загрози, які є найбільшою небезпекою для економіки). Практичне значення. У статті обгрунтовано, що для подальшого покращення привабливості України для інвестування необхідно підвищувати якість правових та організаційних засад, які гарантуватимуть економічну безпеку держави для того, щоб забезпечити сприятливий клімат для інвестування та розвивати конкурентну спроможність національної економіки. Перспективи подальщих досліджень авторів полягають у розробці концептуальних засад інвестиційної безпеки України з урахуванням викликів і загроз глобалізації.

Ключові слова: іноземне інвестування, економічна безпека, загрози економічній безпеці, джерела ризиків та загроз, фінансова безпека, класифікація загроз.

Кількість джерел: 18; кількість таблищь: 0; кількість рисунків: 6; кількість формул: 0.

\section{Introduction.}

Favorable investment climate is one of Investment attractiveness is influenced not the main indicators, which affects investment only by general economic conditions, but also attraction in the economy of the country. by economic security, guaranteed by the state.

\footnotetext{
${ }^{1}$ Національна академія статистики, обліку та аудиту; завідувач кафедри фінансів, банківської справи та страхування; ORCID ID: https://orcid.org/0000-0001-9410-6428; e-mail: bondaruk23@ukr.net.

${ }^{2}$ Національна академія статистики, обліку та аудиту; викладач кафедри фінансів, банківської справи та страхування; ORCID ID: https://orcid.org/0000-0002-3472-9516; e-mail: bondaruk001@ukr.net.

${ }^{3}$ ДВНЗ «Київський національний економічний університет імені Вадима Гетьмана»; професор кафедри корпоративних фінансів і контролінгу; ORCID ID: https://orcid.org/0000-0001-6189-9927; e-mail: kulish.anna@ukr.net.
} 
The range of risks and threats to economic security, that manifests itself traditionally and is associated primarily with the volume of production and fulfilling the demand, increases drastically when consider the problem from the point of view of human development, improve quality of life. In this case, more and more important role gets the threat of the artificial nature of the occurrence and global distribution, accordingly, increasing the complexity of their detection and prevention.

Providing economic security is associated with groups of risks and threats. For instance, macroeconomical, caused by the deterioration of a conjuncture of the world prices for some export commodities and rising import prices; natural and manmade; technological; agri-environmental; social, resulting from the gap between the standard of living in the countryside and in the city; trade and economic; political, and so on.

The components of the economic security are interdependent. The emergence of threats and risks are interconnected too. The threats to economic security, such as unemployment, reliability of income decline may result in the unavailability of provisions. Threats to environmental security (primarily the degradation of the natural environment, radiation and chemical pollution, risks of new biotechnology) pose an immediate threat to economic security. The special significance of environmental risks evident in the growth of their share, compared to other risks in the structure of threats to economic security, because they become comprehensive.

\section{Literature review.}

The problems of public finances are dealt with rather extensively in the scientific literature, particularly in works of such foreign scientists as J. Buchanan (1950), R. Musgrave (1984) and others. According to J. Buchanan (1950), the public finances, should contribute to long-term development and prosperity. R. Musgrave (1984) as one of the most effective means of solving economic problems, achieve economic stability, an important regulator of the economy, a tool of economic planning considers the state budget. Issues relating to economic security highlighted in the works of such scientists as A. Vlasyuk (2011), V. Senchagov (2009).

However, despite a sufficient level of validity of the proposals to ensure economic security and development of public finance, the emergence and prevent threats and risks to economic security and their impact on investment climate improvement are still far from a decision, which actualizes the need for further research in this area.

\section{Methodology.}

The author used the universal methods of scientific research (induction and deduction), as well as the method of analysis. The classification method was used by author too.

\section{Research objectives.}

The purpose of this paper is to study risks and potential sources of economic security threats, as well as available and necessary resources to neutralize them.

\section{Results and discussions.}

Unstable economic situation and conditions of investment involvement in Ukraine complicate investment activity. Ukraine reminds attractive to the investments, at the same time, it is not out of the way of global economic processes and is integrated enough in the world economy. Therefore, disturbances in internal and external markets make an impact on Ukrainian economy.

Changes in investment climate is demonstrated by the dynamics of direct foreign investments, which is the indicator of changes in level of confidence and country rating. According to the State Statistics Service data, in 20171 630,4 mln USD of foreign investors from 76 countries directly invested USD (Fig. 1).

By December $31^{\text {st }}, 2017$, the most significant levels of investment were aimed at the institutions and organizations, provides financial activity and insurance $-21.6 \%$ and industrial enterprises $-27.3 \%$. Among the main investors are such countries as Cyprus - 25.6\%, the Netherlands - $16.1 \%$, the Russian Federation 
- 11.7\%, the United Kingdom - 5.5\%, and Switzerland - 3.9\% (Fig. 2).

Germany $-4.6 \%$, the Virgin Islands $-4.1 \%$,

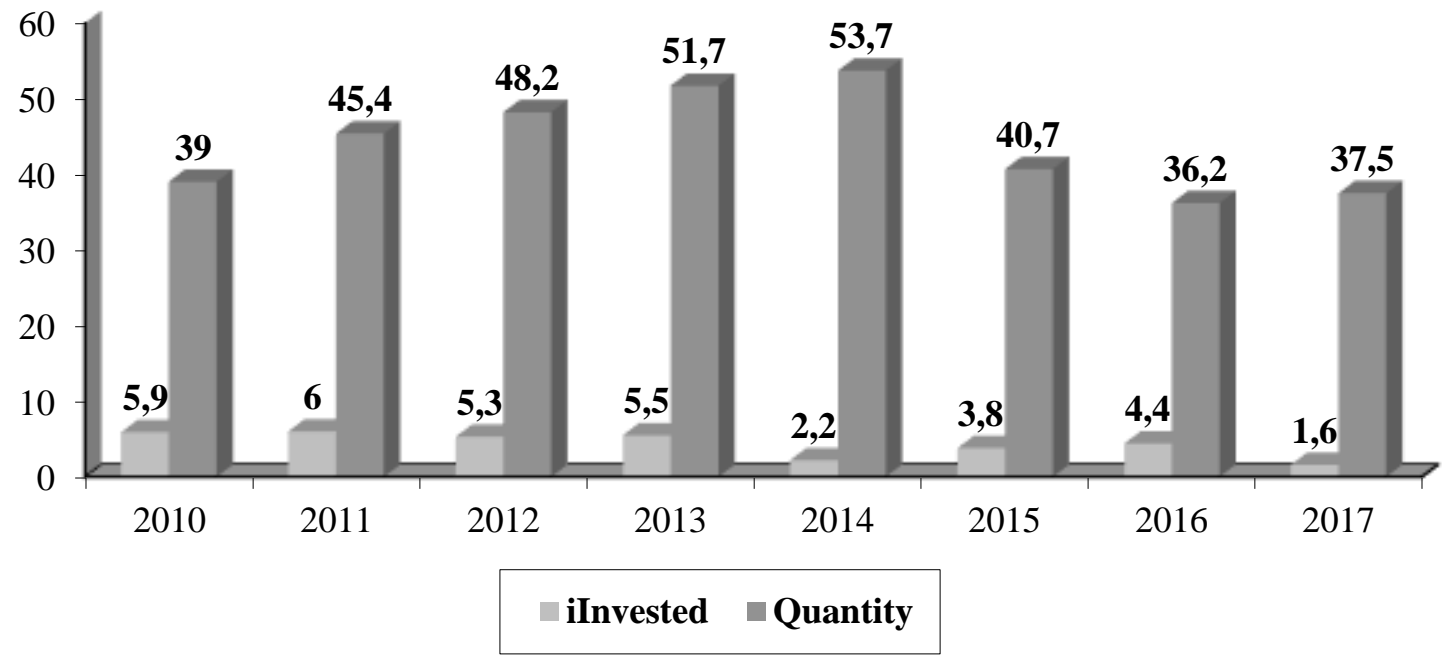

Fig. 1. Direct foreign investment in Ukrainian economy from 2010 to 2017, bln USD Sourse: State Statistics Service of Ukraine (2019).

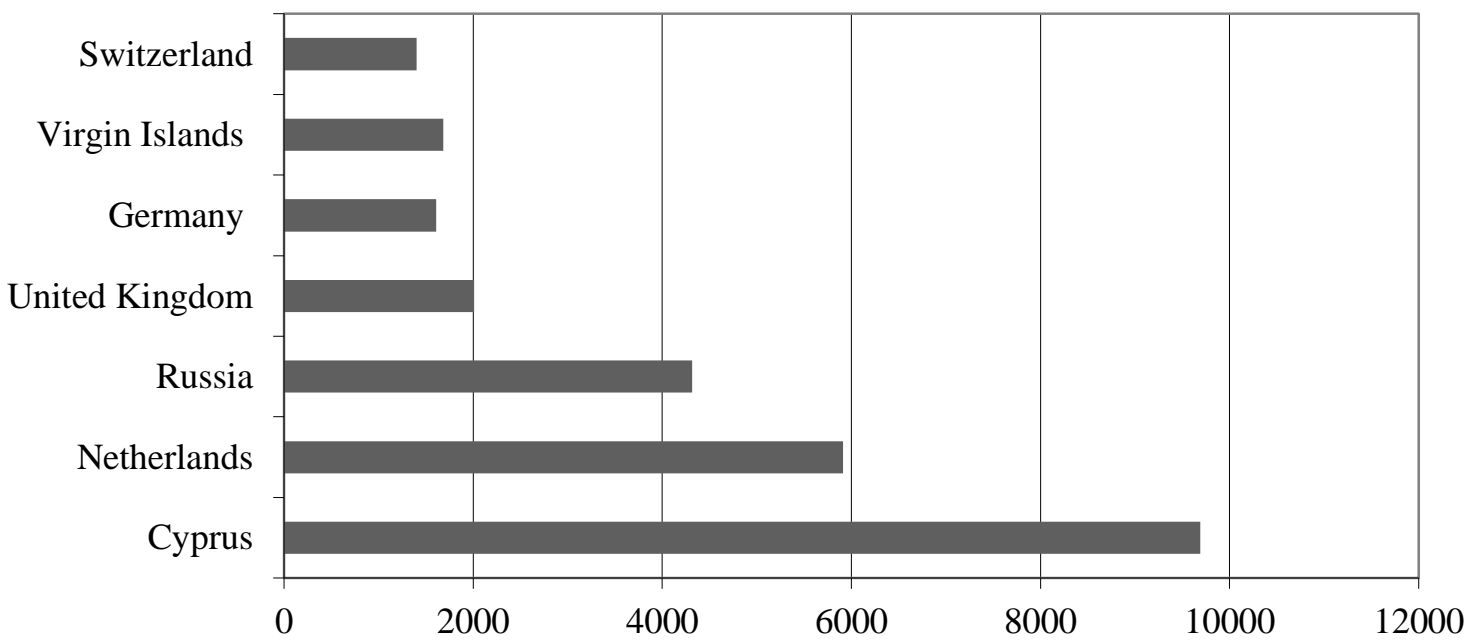

Fig. 2. Direct foreign investment in Ukrainian economy by the main investors from 2010 to 2017, bln USD on 01.01.2017

Sourse: State Statistics Service of Ukraine (2019).

It is seen, that economic activity of foreign investors in Ukraine is insignificant. Among the main reasons of this situation are low ratings of Ukraine. For instance, Ukraine took the $76^{\text {th }}$ place among 190 countries according to Doing Business rating in 2018. However, Ukraine has improved results according to Global Index of Competiveness and held $81^{\text {th }}$ place among 137 countries in $2017 / 2018$ compared to $85^{\text {th }}$ place among 138 countries.
According to BDO International Business Compass rating, Ukraine lost its positions in 2016. In 2015 Ukraine took $89^{\text {th }}$ place, while in 2016 , the $41^{\text {st }}$ position below $-130^{\text {th }}$ place. According to the rating, Ukraine suffered deterioration in all categories, namely, economic, political and socio-cultural). Nevertheless, the decline is particularly marked by economic indicators.

The formation of an effective system of budget security implies a clear identification of 
risks and potential sources of threats, and existing and needed resources to neutralize them.

Exploring issues of financial security I. Semuhin notes that since the $90^{\text {th }}$ of the $20^{\text {th }}$ century, one of the main negative trends in our country was the increase of threats of economic safety of the state. Modern and effective development of economy, restore political and social stability in the country largely depends on the successful policy of the state, particularly in the financial sector (Semukhin, 2008, p. 172). In this regard, one of the actual problems is the state economic security and its main component, which is financial security as defining the conditions for achieving stable economic growth in Ukraine.

Threats to national security by the Law of Ukraine "On fundamentals of national security of Ukraine" is defined as "available and potentially possible phenomenon and factors that endanger the vital national interests of Ukraine" (The Verkhovna Rada of Ukraine, 2003). Threats to the economic security of the state can be defined as potentially possible phenomenon and factors of the negative nature of the economy that affect the economy as a whole and/or its individual elements, which destabilize economic situation in the country and the society, interfere with normal development and cause significant damage to vital interests of individuals, society and the state (Bondaruk, 2017).

Real GDP decline and, as a consequence, the lowered asset values significantly limits the possibility of creating added value in Ukraine, hence - and the security due to the economies of other components of national security. In 2015, Ukraine's GDP amounted to 90,5 (International Monetary Fund, 2016a) $\$$ billion, that is $0.12 \%$ of global GDP and meets the $64^{\text {th }}$ position in the world on this criterion (Fig. 3 and Fig. 4), which limits the international competitiveness of the country. Given that growth of GDP in terms of purchasing power, Ukraine has the worst position for the entire period of independence $\left(116^{\text {th }}\right.$ place out of 187 countries), forming in 2015 only $0.3 \%$ of world GDP (against $0.45 \%$ of the average during $1996-2008$ and $0.4 \%$ respectively during 2009-2013). The GDP per capita, PPP in US dollars in Ukraine is under half size of the world average (7.5 thousand dollars., or $42 \%$ of the average GDP per capita in PPP in 2015) (Bazyliuk, et al., 2017).

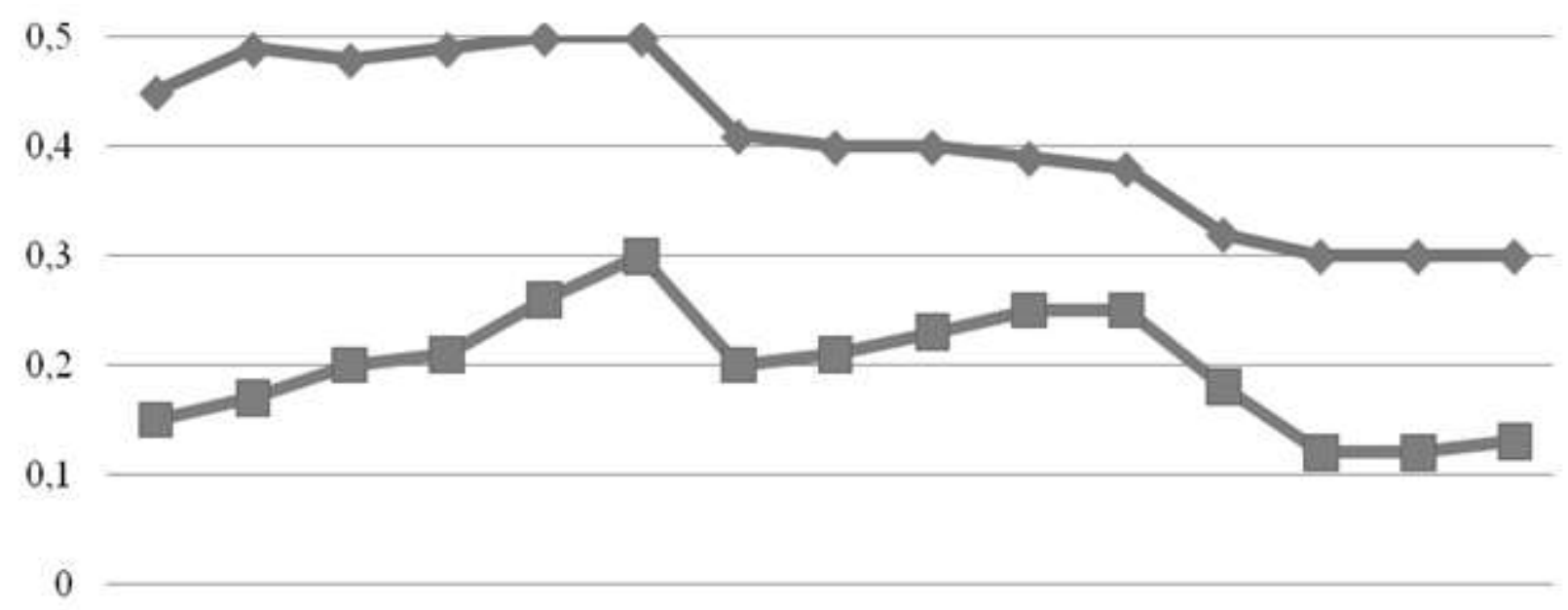

200320042005200620072008200920102011201220132014201520162017

- The share of Ukraine in world GDP by PPP, \%

- The share of Ukraine in world GDP at face value, \%

Fig. 3. The share of Ukraine in world GDP in 2003-2017

Sourse: International Monetary Fund (2016). 


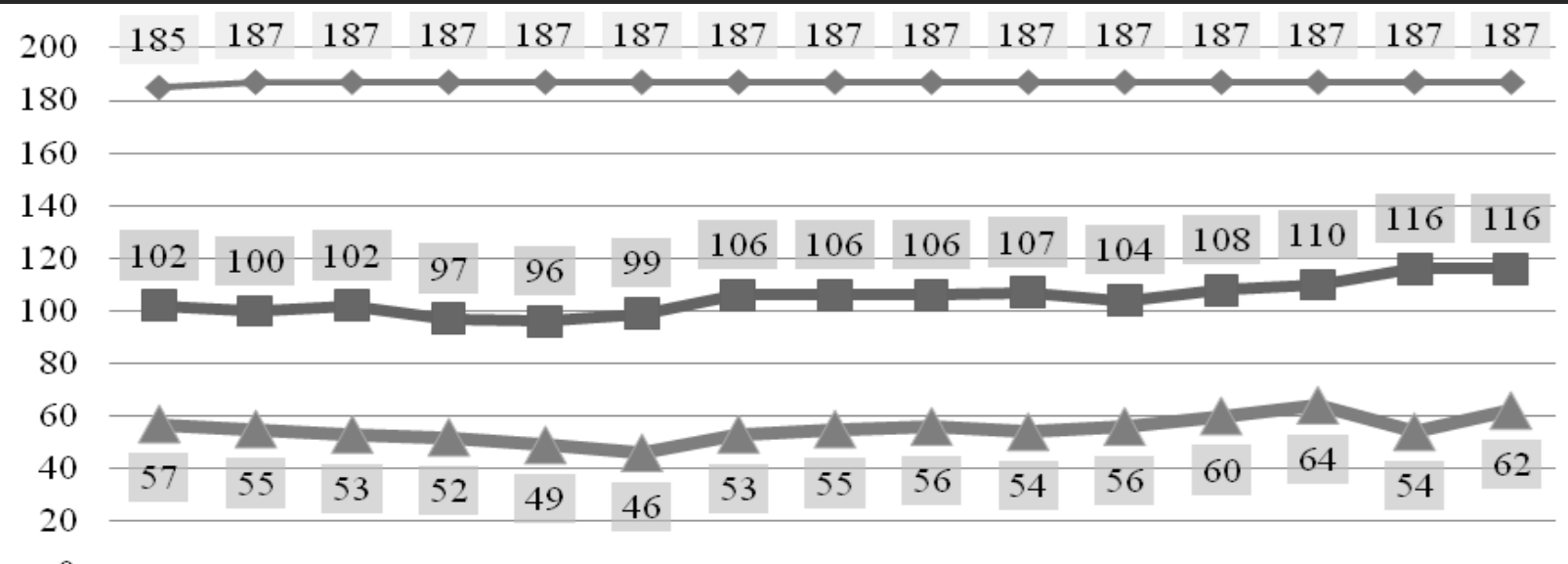

200320042005200620072008200920102011201220132014201520162017

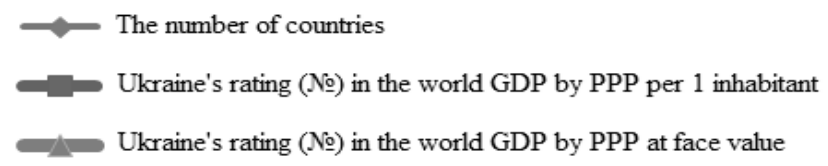

Fig. 4. The place of Ukraine in world GDP in 2003-2017

Sourse: International Monetary Fund (2016a).

Lack of opportunities of national economic model of "survival" under the external hybrid aggression in which economic pressure levers play an important role as well as military and political ones. It contributes to low expectations among international experts regarding the economic recovery of the country.
According to the IMF (Ernste and Schneider, 1998; International Monetary Fund, 2016b), in 2016-2017 possible slight increase of GDP of Ukraine at the level of 1.5$2.5 \%$, which is below the world average growth (3.2 and 3.5\% respectively in 2016 and 2017) (Fig. 5).

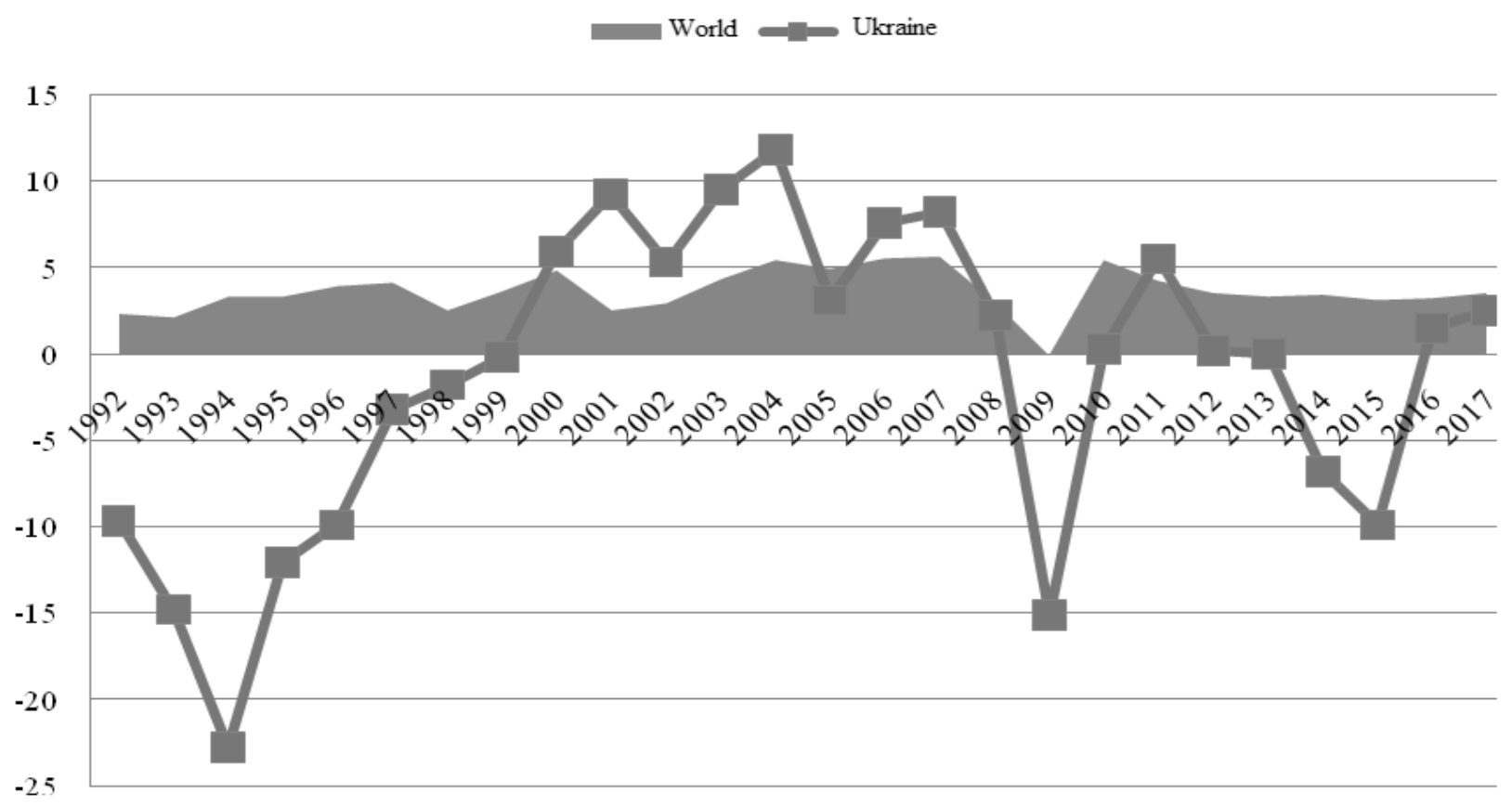

Fig. 5. Dynamics of GDP growth in Ukraine and the world in 1992-2017., \% to the

Sourse: International Monetary Fund (2016a). 
With such pace of economic growth it will take at least 20 years to reach the GDP level of 2008 in dollar terms (while maintaining the equivalent exchange rate of hryvnia to the dollar level 2016) (Bazyliuk, et al., 2017).

Assessing crisis situations are related to the identification and analysis of real and potential threats to economic security in its various segments. Many of the destructive processes in the financial relations are multivariate in the nature and are associated both functionally and structurally, with many macro and micro processes of economic development of the country, making it difficult to identify and pinpoint security threats in the financial sector (Senchahova (ed.), 2005). In any financial and economic activities events and processes of a negative nature may occur. They require thorough analysis, evaluation of the possible consequences, the development of measures to overcome them, which requires some systematization of these phenomenon and processes, their grouping according to similar characteristics. For elaboration of the problems of financial security, all the negative phenomenon and processes in the financial sector are grouped into threats. Thus, the fewer threats to the financial sector of the economy, the better it works.

Uniform and generally accepted classification of threats to economic security does not still exist in domestic science. Therefore, the most common, in our opinion, classification of threats, which distinguish in the economic and financial sectors are the following (Bondaruk, 2017): relative to the object of threats are divided into external and internal; with the likelihood of: unlikely, likely; depending on the causes: spontaneous, deliberate; the magnitude of damage: significant, minor.

By examining threats to the State economic security O. Korystin et al. (2009) proposes to group them into the following blocks:

1. Growth of property, financial and material differentiation of the population, level of poverty increase that leads to destabilization of the social order.
2. Deformation the structure of Ukraine's economy, among a number of reasons calling such as the increase in external debt and an associated increase in expenditure budget for its repayment.

3. The strengthening of uneven socioeconomic development of regions caused by such factors as: the objective differences in the level of socio-economic development of regions, availability depressive, crisis and backward economically regions on the background of structural shifts in industrial production, accompanied while the share of manufacturing industries decreases sharply.

4. The criminalization of society and economic activities. The main factors of this threat are the next: reduction of state control, which resulted in the expansion of the activities of criminal organizations in the domestic financial market, privatisation, export-import operations and the like.

Threats to the economic security Z. Varnalii (2009) and O. Korystin et al. (2009) propose to classify on such parameters:

- place of origin: inner; outer;

- degree of danger: very dangerous; dangerous;

- possibility of fulfilment: real; potential;

- scale of implementation: national; local; individual;

- duration of action: temporary; permanent;

- sphere of action: manufacturing; financial; export-import; technological; institutional; military-economic; socio-economic; demography-economic, ecological-economic, etc.;

- attitude for them: objective; subjective;

- the nature of orientation: direct; indirect.

The content of the threats directly related to its form, which means the ways of external expression of the threat. Form gives the meaning to the threat of actual certainty in the objective world, determines its limits. Due to the form, the threat becomes available for research and evaluation. 
We consider, it is appropriate to complement the existing in domestic literature classification of threats to economic security of its following characteristics.

The reality of the threats - the distribution of the threats from the point of view of assessing the possibility of their occurrence. We believe it is necessary to pay attention primarily to potential threats, which tend to be poorly calculated and their impacts are significant.

Global, national, regional, local - the distribution of threats depending on their spatial location. It is based on the size of the effects contributing to these threats.

Primary and secondary, the distribution of threats depending upon the nature of the reasons between them and the harm suffered. It turns out, whether this loss leads to the damage in other areas (e.g., the shortage of budgetary resources leads to significant problems in the social sphere).

Subjective and objective - the distribution of threats depending on their causes. The main reason subjective threats are the awareness of the harmful actions of individual economic agents, or inefficient work of certain responsible persons. Objective threats are associated with force majeure or similar to them in nature and the sources of its occurrence the circumstances.

In this study, a brief look at the most common in modern science the approach to the distribution of threats to economic security of Ukraine: internal and external.

It should be noted, the internal threats can be understood as a set of negative conditions and factors, the source of which is the economic system; external threats - the totality of conditions and factors that emerged in the economic systems of higher level of hierarchy in relation to this system. Thus, the same threat could be interpreted as internal and as external depending upon the level of hierarchy of the system under study.

Internal threats of economic security are factors that are occurred within the state. These factors, as a rule, are only internal, or start to develop and involve external threats. For example, the budget legislation prohibits the emission of funds of the National Bank of Ukraine to cover the budget deficit, since the result is bound to be inflation, devaluation of the national currency. However, in Ukraine, there is convincing evidence that the issue still occurs. Note that this happens sporadically and now is still the factor of internal threats to financial and budget security of the state. Moreover, certain risks are facts of inappropriate and inefficient use of budgetary funds; weaknesses, including the control in the sphere of budget law; violation of the terms of the budget process (Muzyka-Stefanchuk, 2011).

The external threats include the aggressive behaviour of other states implementing their own national interests in economy and finance on the national territory. External threats of economic security of Ukraine due to as objective processes in the world economy (rapid development of globalization, the instability of the global financial system), as well as specifically problems of economic, financial and budget policy.

Despite the fact that in the long term, foreign influence on Ukraine's economy will grow, and threats to its financial and budget, security from the outside will reflect the following trends:

- the high dependence of the domestic economy from foreign loans (Lohynov, 2005);

- polarization between sectors of the economy that have an access to foreign currency (i. e. to the resources of the world economy), and sectors oriented on the domestic market;

- progressive deterioration of the financial condition of the export-oriented sector of production (Lohynov, 2005);

- the inadequacy of the government response to the conflict escalation in political, economic and social relations, including externally imposed (President of Ukraine, 2007);

- redistribution of funds by state and local budgets across the enterprise with foreign investment in favor of foreign firms, and the like. 
Thus, the external threats to the financial and fiscal security have sources not only outside but also inside the country. Their accounting and a full analysis of external threats to financial security is possible only in the case of compliance to three interrelated processes: global, domestic economic transformations and market (current) economic conditions. All these threats are achievable and have longterm character - the necessary time and significant efforts to counteract them.

Internal threats of financial security, despite the importance of external threats, are the key issues. Their causes are explained by inadequate economic, financial, budgetary policy, low efficiency of management of state and local funds, weak regulatory framework governing the budget process. These reasons included the lack of an integrated system of financial control, weak institutions of state control at the local level, lack of financial control at the local level.

The national security strategy of Ukraine allocates in the internal security problems such threatening national security as (President of Ukraine, 2007):

- the lack of efficiency of state power: the high level and systemic character of corruption in government institutions;

- the imperfection of the legal regulation of social relations, the ineffectiveness of control over observance of legislation;

- the lack of efficiency of using of material resources, including resources of budgetary institutions;

- inefficient use of funds state budget and local budgets;

- the imperfection of the legislation to accelerate the development of the national economy on innovative principles, a relatively high level of illicit economy, the lack of sufficient incentives for legalization of the incomes and reduction of hidden employment.

It is necessarily to analyze the threats, which are primarily directly related to abuses and deficiencies that occur when working with budgetary funds, which affect the required level of stability, efficiency and targeting of budgetary funds. From an economic point of view, these threats can be grouped as follows: lack of clear goals and outcome of the use of budget funds; the limited authorities and responsibilities for recipients of budgetary funds at formation and budget execution; the absence of a clear consolidation of the revenues of the budget system in the recipient appropriate means; the provision of budget funds on the basis of adjustments (indexing) of appropriations from previous years excluding the funded areas of activities in accordance with the priorities of the state policy; formal methods of using program-target budget planning (including the development and implementation of state target programs); the absence of an effective system of state financial control.

In the strategy of national security of Ukraine, the attention is drawn to the fact that other threats, defined by the Law of Ukraine "On fundamentals of national security of Ukraine" remain actual (The Verkhovna Rada of Ukraine, 2003). Their main characteristics, that affect the budget security, are the followings (The Verkhovna Rada of Ukraine, 2003):

- the spread of corruption, bribery in public authorities, accretion of business and politics, organized criminal activity;

- abuses by state authorities and bodies of local self-government of the Constitution and laws of Ukraine, rights and freedoms of man and citizen, including the lack of effective control over compliance with the requirements of the Constitution and laws of Ukraine;

- a significant reduction in gross domestic product, decline in investment and innovation activity and scientific-technical and technological potential, reduction in research in strategically important areas of innovative development;

- the weakening of the system of state regulation and control in the sphere of economy;

- instability in the legal regulation of relations in the sphere of economy, including financial (fiscal) policy of the state; 
- the lack of effective programmes for the prevention of financial crises;

- insufficient rates of reproductive processes and of overcoming the structural deformation in the economy;

- the critical dependence of the national economy on external markets, the slow pace of expansion of the domestic market;

- irrational structure of export predominantly primary character and low specific gravity products with high added value;

- large debt dependence of the state, the critical volume of the state external and internal debts;

- threat to the economic independence of Ukraine the growth in the share of foreign capital in strategic sectors of the economy;

- "shadowing" of the national economy;

- the predominance in the management structures of personal, corporate, regional interests over national.

Internal threats to the budget security are inseparable from certain threats to economic security, including the deformed structure of the domestic economy, the crisis, the deterioration of the innovation potential, low competitiveness of domestic products, the uneven socio-economic development of regions, criminalization of economic activities, corruption, the reduction of the gross domestic product and so on (Bondaruk, 2017).

Between the economic threats to national security and threats in the public sector, there is a causal relationship: each of the threats is the reason in one case and the cause in another one. For example, the unstable financial condition of most economic subjects due to economic policy, which, in turn, largely depends on the financial resources of the state. The boundaries between internal and external threats are not always clear. Often they determined each other.

However, it is clear that the long-term conservation of the threats in the national economy of the country makes it vulnerable on a global scale. For example, in the deteriorating socio-economic dynamics of Ukraine's development, due to the destabilizing actions of the Russian Federation, precising phenomenon in the economy and the unfavourable external environment has worsened the state of economic security of Ukraine. The national economy showed a low ability to counteract internal and external threats.

Threats to economic security of the agricultural sector have different forms of manifestation, and their origin and influence due to many factors. Regarding the characteristics underlying the classification of the sources of threats to economic security, types of threats may vary depending on (Fig. 6).

\section{Conclusions.}

As a result of the analysis of existing approaches to identification of risks and the sources of threats to economic security, the threats to economic security could be classified into several groups, which have different manifestations and signs, laid into the basis for classification, vary depending on:

- the degree of versatility - general and specific;

- managerial influence - managed and unmanaged;

- in relation to the system - internal and external;

- duration - constant,

- long-term and short-term;

- the sources of origin - natural (natural element),

- artificial (man-made),

- mixed (human activities that contribute to the occurrence of natural disasters);

- on a territorial prevalence - global, regional, national (within defined national boundaries) and local;

- the method of action - open (explicit) and hidden (latent);

- the likelihood of appearance - real, potential, unlikely, and highly probable;

- nature of occurrence - intentional and unintentional (as a natural or unexpected side result of certain acts or events);

- areas of occurrence - legal, economic, political and social;

- the nature of the action - appear gradually or suddenly; causing damage directly or indirectly;

- according to the degree of danger - with 
consequences that can be addressed;

- that cannot be resolved and which can

be removed partially, if possible;

- the possibility of preventing - those that can be prevented completely,

- partially, and which cannot be prevented completely.

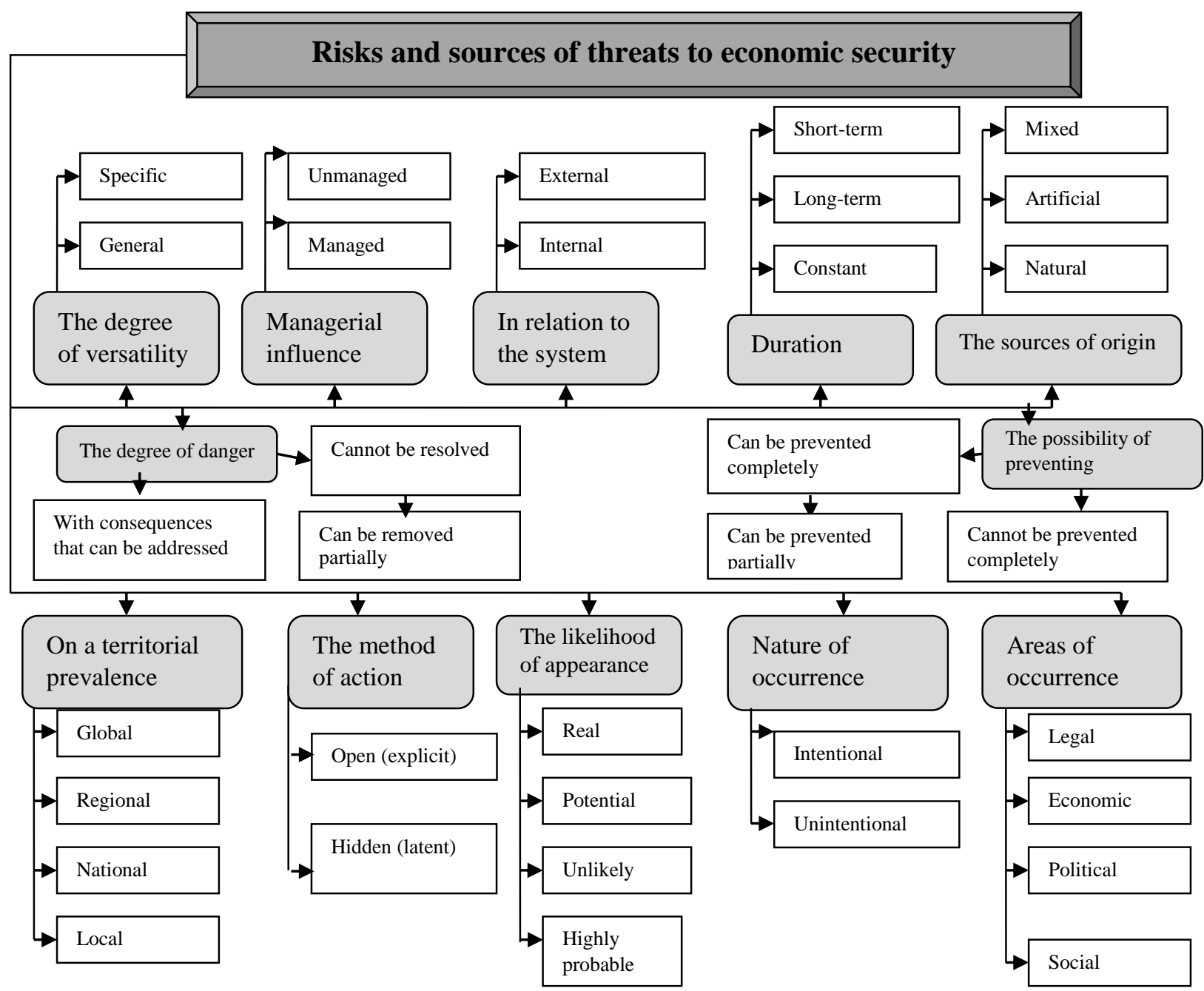

Fig. 6. Classification of risks and sources of threats to economic security

Sourse: Compiled by the authors.

Proposed classification of risks and sources of threats to economic security would contribute to the implementation of a rational system of state regulation of economic security. It would link all the stages and steps of analysis, prediction, selection, regulatory measures, and financial and information support of economic development into a single system to prioritize economic security, structuring the goals and objectives of economic development, identifying risk areas and sources of threats to economic security, justification of the priority directions of its detection and prevention.

For further investment of economic attractiveness of Ukraine, the issue of legal and organization improvement is relevant to guaranty State economic security to provide favorable investment climate and develop competiveness of the national economy.

\section{References}

Bazyliuk, Ya. B., Davydenko, S. V., Ventskovskyi, D. Yu., Sharov, O. M., Liapin, D. V., Vlasiuk, T. O., Pokryshka, D. S., Haluhan, N. V. and Us, I. V. (2017), Ekonomichna bezpeka Ukrayiny $v$ umovakh hibrydnoyi 
ahresiyi [Economic security of Ukraine in the context of a hybrid of aggression], NISD, Kyiv, Ukraine, $84 \mathrm{p}$.

Bondaruk, O. S. (2017), "Analysis of budget threats and their impact on the financial security of Ukraine", International relations, part "Economic sciences", [Online], no. 1, available at: http://journals.iir.kiev.ua/index.php/ec n/article/view/3275 (Accessed 3 March 2019).

Buchanan, J. M. (1950), “Federalism and fiscal equity”, The American Economic Review, vol. 40, no. 4, pp. 583599.

Ernste, D. and Schneider F. (1998), "Increasing shadow economies all over the world - Fiction or reality?", Discussion Paper No. 26, 65 p, available at: http://ftp.iza.org/dp26.pdf (Accessed 3 March 2019).

International Monetary Fund (2016a), "World economic outlook April 2016. IMF Data mapper", available at: http://www.imf.org/external/datamapper/index.php (Accessed 3 March 2019).

International Monetary Fund (2016b), "World economic outlook. IMF (October 2016)", available at: http://www.imf.org/externai/pubs/ft/weo/2016/01/pdf/text.pdf (Accessed 3 March 2019).

Korystin, O. Ye., Baranovskyi, O. I., Herasymenko, L. V., Dolia, L. M., Kaliuk, O. M. and Dzhuzha, O. M. (ed.) (2010), Ekonomichna bezpeka [Economic security], Vseukrainska asotsiatsiia vydavtsiv "Pravova yednist", Alerta, KNT, Tsentr uchbovoi literatury, Kyiv, Ukraine, 368 p.

Lohynov, E. L. (2005), Stratehyy ékonomycheskoy voyny: Konfrontatsyya heoékonomycheskykh konkurentov yz SSSR y Rossyey [The strategy of economic war: Confrontation, geo-economic competition from the Soviet Union and Russia], YUNYTY-DANA, Moscow, Russia, 98 p.

Musgrave, R. A. (1984), Public finance in theory and practice, McGraw-Hill Book Company, New York, USA, $824 \mathrm{p}$.

Muzyka-Stefanchuk, O. A. (2011), "Some questions on the financial and budget security of the state", Mytna sprava, no. 4(76), pp. 82-85.

President of Ukraine (2007), Decree of the President of Ukraine "On the strategy of national security of Ukraine”, available at: https://zakon.rada.gov.ua/laws/show/105/2007 (Accessed 3 March 2019).

Semukhin, I. Yu. (2008), "Regional aspects of financial safety of Ukraine: system modeling fiscal relations", Scientific Notes of Taurida National University. V. I. Vernadsky, no. 21, pp. 172-178.

Senchahov, V. (2009), "Strategic objectives and a mechanism to ensure economic security", Problems of theory and practice of management, no, 3, pp. 18-23.

Senchahova, V. K. (ed.) (2005), Ékonomycheskaya bezopasnost' Rossyy: Obshchyy kurs [Economic security of Russia: General course], Delo, Moscow, Russia, 429 p.

State Statistics Service of Ukraine (2019), "Foreign economic activity", available at: http://www.ukrstat.gov.ua/operativ/menu/menu u/zed.htm (Accessed 3 March 2019).

The Verkhovna Rada of Ukraine (2003), The Law of Ukraine "On the fundamentals of national security of Ukraine”, available at: http://zakon4.rada.gov.ua/laws/show/964-15 (Accessed 3 March 2019).

Varnaliya, Z. S. (ed.) (2009), Ekonomichna bezpeka [Economic security], Znannya, Kyiv, Ukraine, 647 p.

Vlasyuk, O. S. (2011), Ekonomichna bezpeka Ukrayiny $v$ umovakh rynkovykh transformatsiy ta antykryzovoho rehulyuvannya [Economic security of Ukraine in conditions of market transformations and anti-crisis regulation], DNNU «Academy of financial management», Kyiv, Ukraine, 474 p.

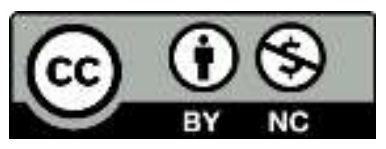

Цей твір ліцензовано на умовах Ліцензії Creative Commons «/з Зазначенням Авторства - Некомерційна 4.0 Міжнародна» (CC BY-NC 4.0).

This is an open access journal and all published articles are licensed under a Creative Commons "Attribution-NonCommercial 4.0 International" (CC BY-NC 4.0). 